\title{
КЛАСИФІКАТОР СТАНУ ПЕЧІНКИ У ДІТЕЙ 3 ПАТОЛОГІЕЮ ГЕПАТОБІЛІАРНОЇ СИСТЕМИ ЗА ТЕКСТУРНИМИ СТАТИСТИКАМИ УЛЬТРАЗВУКОВОГО ДОСЛІДЖЕННЯ
}

\author{
Настенко С.А., зав. каф., д.б.н., к.т.н., с.н.с. \\ nastenko.e@gmail.com \\ Янковий I.О., студент \\ illia.yankovyi@gmail.com \\ Факультет біомедичної інженерії \\ Національний технічний університет \\ «Київський політехнічний інститут імені Ігоря Сікорського» \\ м. Київ, Україна
}

Реферат - За результатами ультразвукового дослідження печінки можна діагностувати наявність дифузних захворювань печінки.На вході було отримано набір медичних зображень ультразвукової діагностики печінки. В даній роботі до зображень було застосовано методи текстурного аналізу, внаслідок чого було отримано 96 статистичних ознак. Всі отримані дані були приведені до стандартного розподілу. Кількість ознак була скорочена при збереженні вагомої інформації за допомогою ядровоі методики головних компонент. Розглянуто побудову моделі класифікатора, наведено порівняння ефективності моделі випадкового лісу, логістичної регресії та багатошарового периептрону. Проведено оиінювання точності моделі за допомогою методу перехресної перевірки. Найкращий результат показала модель мультиноміальної логістичної регресії - 77\%. Розроблено систему для прогнозування можливих патології печінки у дітей за допомогою текстурного аналізу результатів сонографії. Отримана система візуалізує результати прогнозування та їх точність для спрощення процесу прийняття рішень лікарем з ультразвукової діагностики.

Ключові слова - класифікація, текстурний аналіз, текстурні статистики, метод головних компонент, ядрові методи, перехресна перевірка, дифузні захворювання печінки, ультразвукова діагностика, дитячі захворювання.

\section{I. ВСТУП}

У 2015 році вірусний гепатит привів до 1,34 мільйонів смертей, кількість жертв нарівні 3 туберкульозом (1,37 мільйона смертей), що вище, ніж через вірус імунодефіциту людини (1,06 мільйонів смертей) чи малярію $(0,44$ мільйона смертей) [1]. Діагностика дифузних захворювань печінки надзвичайно важлива тому що може передбачити ці патології допомогти запобігти їх більш складним наслідкам, таким як цироз та гепатоцелюлярна карцинома.

Стверджується, що біопсія печінки $\epsilon$ золотим стандартом діагностики захворювань печінки, але цеінвазивна процедура, що може призвести до деяких важких ускладнень у 1-3 31000 випадків [2]. Ультразвукове дослідження $\epsilon$ неінвазивним i тому менш небезпечним. Однак, такий підхід має ряд проблем. До них можна віднести точність та швидкість поставлення діагнозу. В порівнянні 3 такими патологоанатомічними методами як біопсія печінки, що потребує хірургічного втручання, інформативність неінвазивного підходу сонографії нижче та залежить від лікаря, що проводить діагностику. Також, для остаточного встановлення діагнозу на основі цього методу потрібне рішення кількох лікарів, що теж займає певний час. Тому важливим $\epsilon$ створення класифікатора, що міг би швидко та 3 високим рівним точності прогнозувати ймовірність тих чи інших патологій печінки у пацієнта за результатами ультразвукового дослідження.

Розробка статистичного алгоритму класифікації можлива лише при наявності достатньо великої бази даних пацієнтів 3 патологіями гепатобіліарної системи. Для цього потрібен раціональний метод виділення 
ознак із зображень сонографії, статистична модель, яка могла би прогнозувати стан печінки пацієнта із високим рівнем точності.

\section{II. МЕТА ДОСЛІДЖЕННЯ}

Огляд методів текстурного аналізу для обробки медичних зображеннь. Побудова моделі класифікації дифузних захворювань печінки у дітей. Розробка програмного продукту для користування вказаною моделлю.

\section{ІІІ. МАТЕРІАЛИ ДОСЛІДЖЕНЬ}

Дослідження зосереджене на текстурних ознаках медичних зображень ультразвукової діагностики (на областях інтересу, які попередньо позначені клініцистами) для виявлення дифузних захворювань печінки. Для виконання цієї роботи було використано набір 3104 зображень ультразвукової діагностики у 15 пацієнтів дитячого віку.

Було використано методи проектування ознак: текстурні статистики 1-го, 2-го і вищих порядків. Використано методи виділення ознак: метод головних компонент (МГК); ядровий метод головних компонент (ЯМГК). Точність класифікації була визначена за допомогою 5-кратної перехресної перевірки.

\section{IV. ОГЛЯД ЛІТЕРАТУРИ}

Дифузні захворювання печінки - група захворювань, основна особливість яких полягає в тому, що кожне 3 них викликає хронічне запалення печінки, процес, при якому відбувається щоденний розпад печінкових клітин. Хронічне запалення, в свою чергу, спричиняє виникнення та прогресування фіброзу печінки [3].

Фіброз - ущільнення сполучної тканини у результаті хронічного запалення. В результаті цього процесу у враженому органі виникають рубці, за допомогою яких організм намагається ізолювати осередок запалення. Тривале збереження фіброзу без лікування може 3 часом викликати його прогресування та більш серйозні патологічні наслідки для людини [4].

Гістологічна оцінка вираженості фіброзу печінки часто виконується за системою METAVIR за 5-рівневою шкалою (F0-F4), де F0 - відсутність фіброзу, F4 - цироз печінки.

Фіброз печінки може бути викликаний надмірним споживанням алкоголю або хронічним запалення печінки, індуковане вірусом. Інші фактори, які можуть призвести до рубцювання печінки, включають застосування деяких лікарських засобів, опромінення, механічна травма, наявність жирових захворювань печінки та генетичні розлади. Фіброз печінки - клінічно значущий процес, який є попередником цирозу печінки.

Відомо, що всі пошкодження печінки, що найчастіше викликають за собою розвиток цирозу, викликають також i фіброз. Найважливішими агентами, що викликають пошкодження такого характеру за клінічними даними вважають алкогольну і неалкогольну жирові хвороби печінки, хронічний вірусний гепатит В i C, генетично обумовлені гепатопатії (до яких, наприклад, належить хвороба Вільсона, гемохроматоз, дефіцит альфа-один-антитрипсину), а також захворювання, індуковані впливом лікарських препаратів i токсинів, аутоімунні захворювання печінки, а також хронічна правобічна серцева недостатність [5].

Цироз - кінцевий етап накопичення елементів позаклітинної сполучної тканини, які деформують балочну структуру часточок печінки і їі мікроциркуляторного русла (МЦР) за рахунок формування рубців, 3 подальшим розвитком осередків регенерації гепатоцитів. При цирозі відбувається порушення всіх функцій печінки. Цироз збільшує ризик розвитку раку печінки, що виникає внаслідок прогресування гепатоцелюлярної карциноми $[6,7]$.

Ультразвукова діагностика (сонографія, ультрасонографія) - метод променевої діагностики, при якому використовуються високочастотні звукові (ультразвукові) хвилі. Для отримання зображення внутрішніх органів людського тіла використовується реєстрація відбитих від внутрішніх поверхонь ультразвукових хвиль [8].

За останнім дослідженням [9], що включає в себе аналіз 43 попередніх робіт за даною темою, ультразвукове дослідження має чутливість діагностичного тесту в діапазоні 73.3-90.5\% та специфічність в діапазоні між 69.6-85.2\% в порівнянні з біопсією печінки.

Однією 3 найбільш ефективних сучасних методик ультразвукової діагностики печінки стану пацієнта вважають еластографію. За останніми експериментальними даними, цей метод дає точність діагностики для різних 
стадій фіброзу: F0-F1 - 88-90\%, F2-F3 - 90-94, F4 - 94-98\% [10].

Радіоміка - область медичного дослідження, що має на меті отримання кількісних ознак 3 медичних зображень, 3 використанням алгоритми визначення характеристик даних. Одним 3 видів таких зображень $є$ зрізи текстури паренхіми печінки, що отримують в результаті сонографії. Текстура - зображення, що відображає візуальні властивості певної поверхні або об'єкта.

Текстура містить значну кількість важливої інформації для класифікації певних видів об'єктів. Ця інформація може бути отримані 3 неї різними способами. Одним зі способів $є$ TA (текстурний аналіз). Це гілка науки про зображення, понад усе зацікавлена описом властивостей зображень за допомогою текстурних ознак [11]. Основна ідея ТА полягає в обчисленні цих ознак на основі просторових відносин сірого тону зображення. Текстурні статистики поділяються на властивості першого і вищого порядків. Статистичні особливості першого порядку обчислюються 3 гістограми інтенсивності зображення. Статистичні особливості другого та вищих порядків отримуються з різних видів матриць відносин сірих рівнів зображення.

Матриці сірих рівнів:

1. матриця суміжності GLCM (англ. GreyLevel Co-Occurrence Matrix) [12, 13]

2. матриця довжини пробігу GLRLM (англ. Grey-Level Long Run Matrix) [14]

3. матриця розміру зони GLSZM (англ. Grey-Level Size Zone Matrix) [15]

4. матриця залежності GLDM (англ. GreyLeve lDependence Matrix) [16]

5. матриця різниці за сусідством NGLDM (англ. Neighborhood Grey-Level Difference Matrix) [17]

GLCM- це матриця, яка виражає, як комбінації дискретизированних інтенсивностей сусідніх пікселів або вокселів розподіляються за одним 3 напрямків зображення.

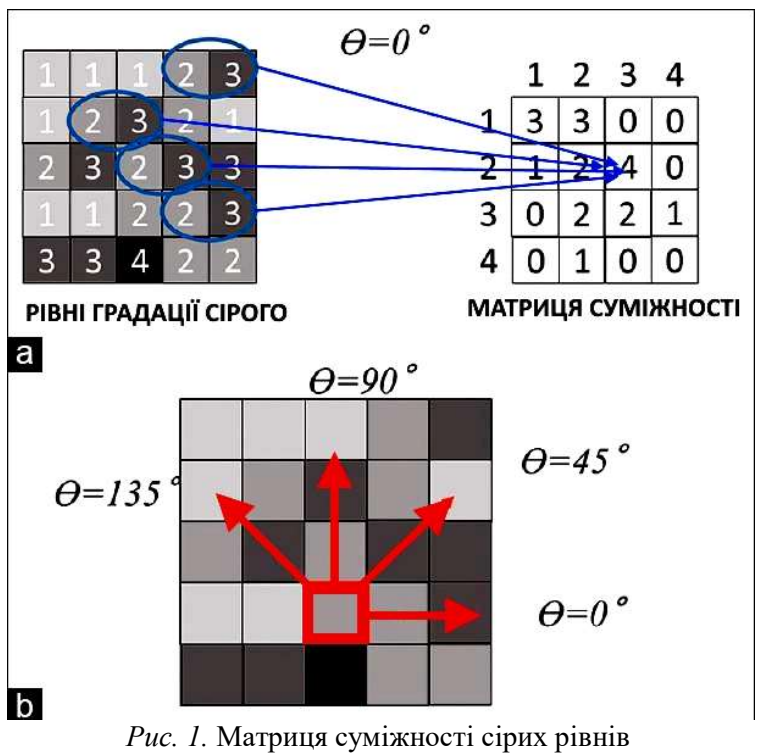

GLRLM- це матриця, яка оцінює довжину пробігу в розподілі дискретизованих рівнів сірого зображення. Довжина пробігу визначається як довжина послідовності пікселів або вокселів 3 однаковим рівнем сірого уздовж певного напрямку. Матриця GLRLM містить кількість випадків пробігів 3 довжиною ј для дискретизованого рівня і [18].

Image

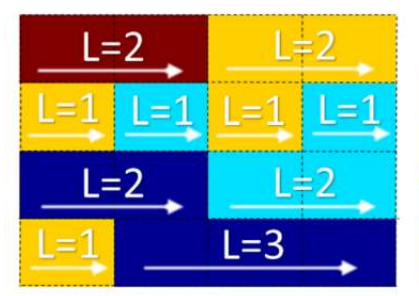

Puc. 2. Матриця довжини пробігу сірих рівнів [18]

GLSZM- це матриця, яка підраховує кількість зон пов'язаних пікселів або вокселів. Піксель або воксель пов'язані, якщо сусідній піксель або воксель має ідентичний дискретизований рівень сірого.

\section{Image}

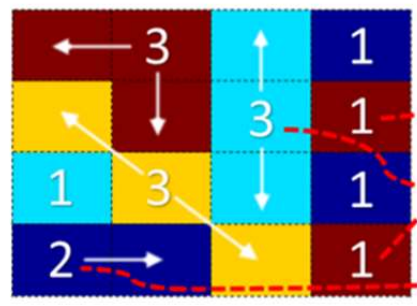

Puc. 3. Матриця розміру зони сірих рівнів [18]
Size Zones

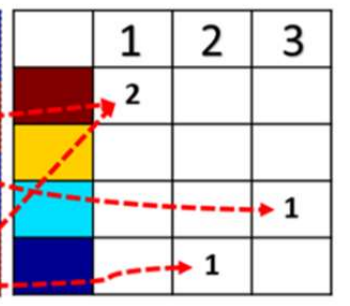

GLDM- це матриця, яка має на меті підрахувати грубість текстури загалом, а 
також визначити чи вона є інваріантною при обертанні.

dependence $k$

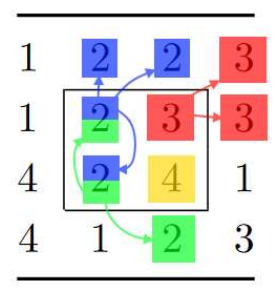

(a) Grey levels

\begin{tabular}{cccccc}
\multicolumn{5}{c}{ dependence $k$} \\
& & 0 & 1 & 2 & 3 \\
\hline & 1 & 0 & 0 & 0 & 0 \\
$i$ & 2 & 0 & 0 & 1 & 1 \\
& 3 & 0 & 0 & 1 & 0 \\
& 4 & 1 & 0 & 0 & 0 \\
\hline
\end{tabular}

(b) Neighbouring grey level dependence matrix Puc. 4. Матриця залежності сірих рівнів [18]

NGLDM- це матриця, яка містить суму різниці рівнів сірого пікселя або вокселя 3 дискретизованим рівнем сірого і та середнім рівнем дискретизації сірого сусідніх пікселів або вокселя.

\begin{tabular}{llll}
\hline 1 & 2 & 2 & 3 \\
1 & 2 & 3 & 3 \\
4 & 2 & 4 & 1 \\
\cline { 2 - 3 } 4 & 1 & 2 & 3 \\
\hline
\end{tabular}

(a) Grey levels

\begin{tabular}{ccccc}
\hline & & $n_{i}$ & $p_{i}$ & $s_{i}$ \\
\hline & 1 & 0 & 0.00 & 0.000 \\
$i$ & 2 & 2 & 0.50 & 1.000 \\
& 3 & 1 & 0.25 & 0.625 \\
& 4 & 1 & 0.25 & 1.825 \\
\hline
\end{tabular}

(b) Neighbourhood grey tone difference matrix
Puc. 5. Матриця різниці сірих рівнів за сусідством [18]

де $s_{i}-$ абсолютна різниця між інтенсивністю пікселя чи вокселя і середньою сумою інтенсивностей сусідів.

$$
\begin{aligned}
& s_{2}=|2-19 / 8|+|2-21 / 8|=1 \\
& s_{3}=|3-19 / 8|=0.625 \\
& s_{2}=|4-17 / 8|=1.825
\end{aligned}
$$

3 основних матриць сірих рівнів може бути вилучено набір специфічних для кожної $з$ них ознак на основі інтенсивності рівня сірого. Всі розроблені на даний момент ознаки матриць сірого рівня описані у дослідженні 3 їх стандартизації [19].

Загальною вимогою для багатьох методів машинного навчання (таких як метод опорних векторів, логістична регресія i штучні нейронні мережі) $\epsilon$ стандартизація наборів даних [20]. Вони можуть погано працювати, якщо окремі властивості не виглядають схожими на стандартні нормально розподілені дані (розподіл Гауса), що характеризується густиною ймовірності:

$$
f(x ; \mu, \sigma)=\frac{1}{\sigma \sqrt{2 \pi}} \exp \left(-\frac{(x-\mu)^{2}}{2 \sigma^{2}}\right)
$$

де $x$ - базовий вектор ознак,

$\mu$ - математичне сподівання,

$\sigma^{2}$-дисперсія випадкової величини.

Розподіл називається стандартним нормальним, якщо $\mu=0, \sigma^{2}=1$.

3 урахуванням отриманої кількості ознак (сучасна програмна бібліотека для текстурного аналізу Pyradiomics для мови програмування Python здатна обчислювати до 75 текстурних ознак), можливе виникнення явища «прокляття розмірності» (англ. Curse of dimensionality). Це явище може шкодити роботі методів, що використовують статистичну значущість. Таким чином, виникає необхідність зменшити кількість ознак. Зменшення розмірності - перетворення даних, що полягає в зменшенні числа змінних шляхом отримання найменшої кількості змінних, які можуть описувати дані.

3 цією задачею справляється метод головних компонент (МГК, перетворення Кархунена-Лоєва).

МГК - це статистична процедура, яка використовує ортогональне перетворення для зміни набору спостережень можливих корельованих змінних (об'єктів, кожен з яких приймає різні числові значення) в набір значень лінійно некорельованих змінних, які називаються основними компонентами [21].

Цей метод зазвичай зводять до одного 3 підходів:

1. Сингулярний розклад матриці даних.

2. Пошук власних векторів і власних чисел коваріаційної матриці початкових даних.

Результати МГК залежать від масштабування змінних. Це можна виправити, масштабуючи кожен елемент за його стандартним відхиленням, щоб в підсумку виходили безрозмірні елементи з одиничною дисперсією. До обмежень МГК слід зарахувати здатність вловлювати лише лінійні кореляції між функціями, але не функціонує, коли це припущення порушується. 


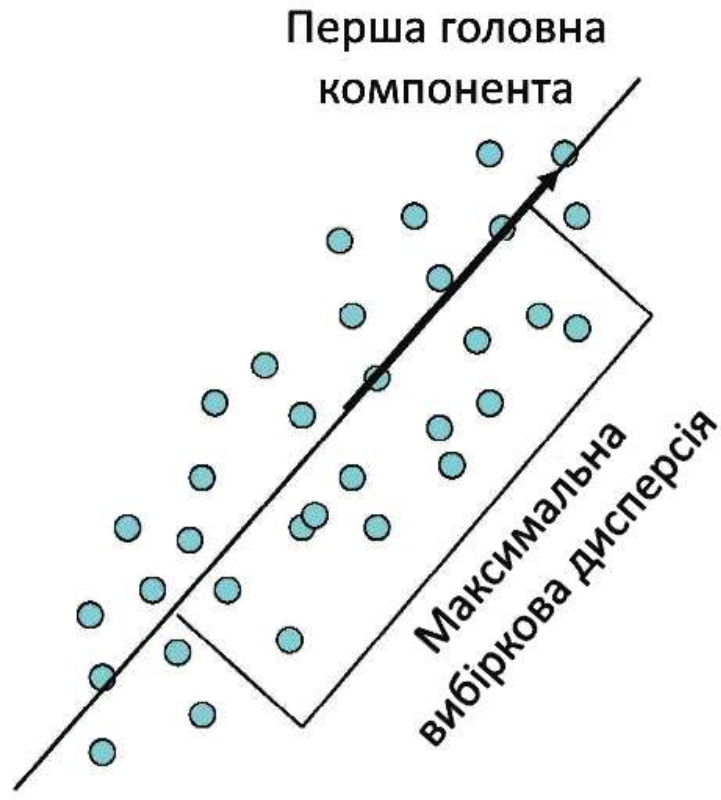

Puc. 6. МГК через пошук ортогональних проекцій 3 найбільшим розсіюванням

Обійти обмеження лінійності можна за допомогою модифікації ядрового методу головних компонент (ЯМГК). Ядрові методи (англ. «kernelmethods») на відміну від інших методик вимагають не явного представлення даних у вигляді вектора ознак, а тільки обраного ядра (функції подібності) між парами точок у первинному їх записі без перетворення. Суть методу полягає в тому, щоб перейти до функцій ядра, які дають можливість працювати з неявним простором без підрахунку координат, а за допомогою підрахунку скалярного добутку відображення всіх пар даних у цьому просторі («ядровий трюк») [22].

Є різні ядрові варіації МГК, що відрізняються один від одного видом функції подібності, яку застосовують. Наприклад:

1) Поліноміальне ядро:

$$
k(x, y)=\left(\gamma x^{T} y+c_{0}\right)^{d}
$$

де х,у - вхідні вектори,

$\gamma-$ нахил (крутизна) неявного простору

$c_{0}-$ вільний доданок

$d-$ степінь ядра

$k(x, y)-$ функція подібності ядра

2) Радіальна базисна функція в якості ядра:

$$
k(x, y)=\exp \left(-\gamma\|x-y\|^{2}\right)
$$

У разі якщо $\gamma=\sigma^{2}$, ядро називають Гауссовим.

Для перевірки точності отриманої аналітичної моделі на незалежних даних необхідно розділити набір даних на навчальну та тестову частину. Цю задачу спроможне вирішити сімейство методів перехресної перевірки (англ. cross-validation). Суть цих методів полягає у розділі даних на $k$ рівних частин, після чого модель навчається на $k-1$ частинах, а частина у залишку використовується для тестування.

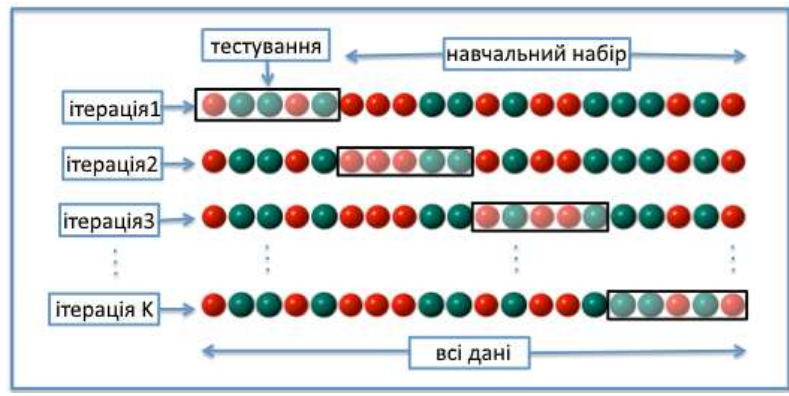

Pис. 7. К-кратна перехресна перевірка $3 \mathrm{k}=4$

Ціль перехресної перевірки полягає в тому, щоб перевірити здатність моделі передбачати нові дані, які не були використані при його оцінці, для того, щоб позначити проблеми, такі як перенавчання класифікатору або систематична помилка відбору, i дати уявлення про те, як модель буде узагальнюватися для незалежного набору даних.

\section{V. РЕЗУЛЬТАТИ ТА ОБГОВОРЕННЯ}

В ході дослідження було прийнято рішення використати методи текстурного аналізу в якості ознак статистичного класифікатору патологічних станів гепатобіліарної системи людини. Було обчислено матриці GLCM, GLRLM, GLSZM, GLDM, NGLDM, а також спеціальні текстурні ознаки до кожної з цих матриць. Кожна 3 отриманих ознак була приведена до розподілу Гауса (стандартизована). Після цього було застосовано метод головних компонент. Точність отриманої аналітичної моделі фіксувалася за допомогою кросвалідації, після чого було обрано та збережено модель із найвищим рівнем точності. 
Для порівняння було використано такі моделі класифікації: випадковий ліс, мультиноміальна логістична регресія (відома як Softmax) та багатошаровий перцептрон.

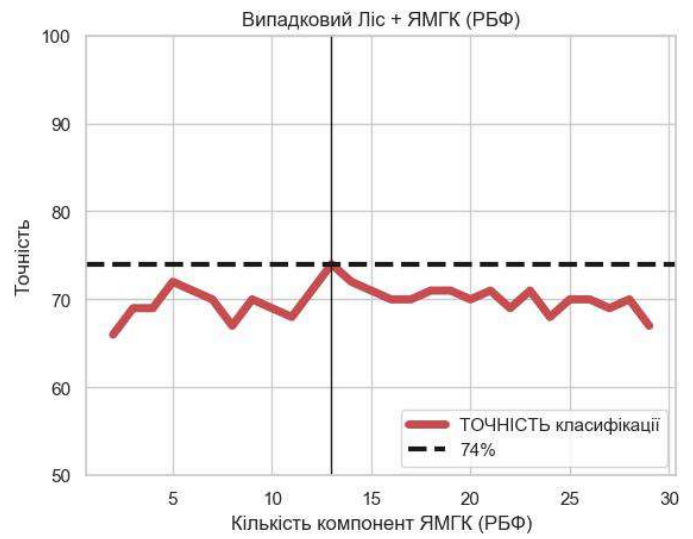

Pис. 8. Точність моделі Випадковий Ліс на ЯМГК (використана радіально-базисна функція) - 74\%

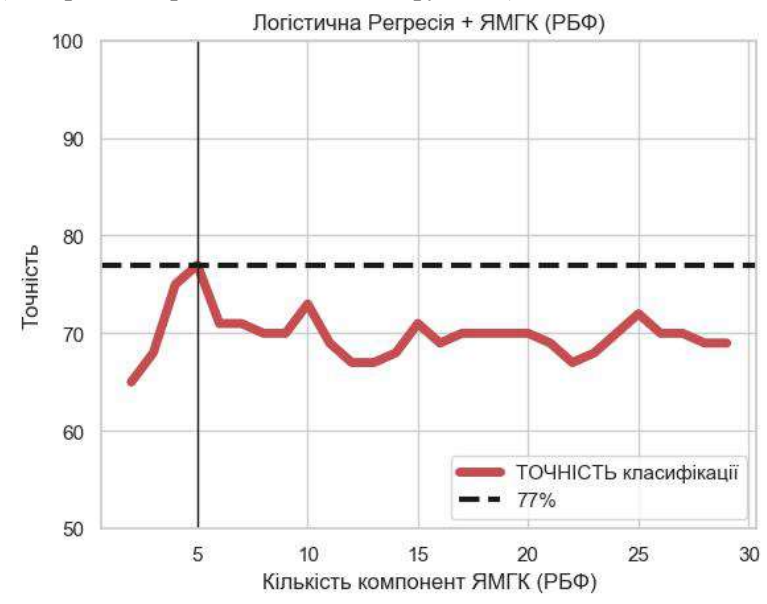

Puc. 9. Точність моделі Логістична Регресія на ЯМГК (використана радіальна базисна функція) - 77\%

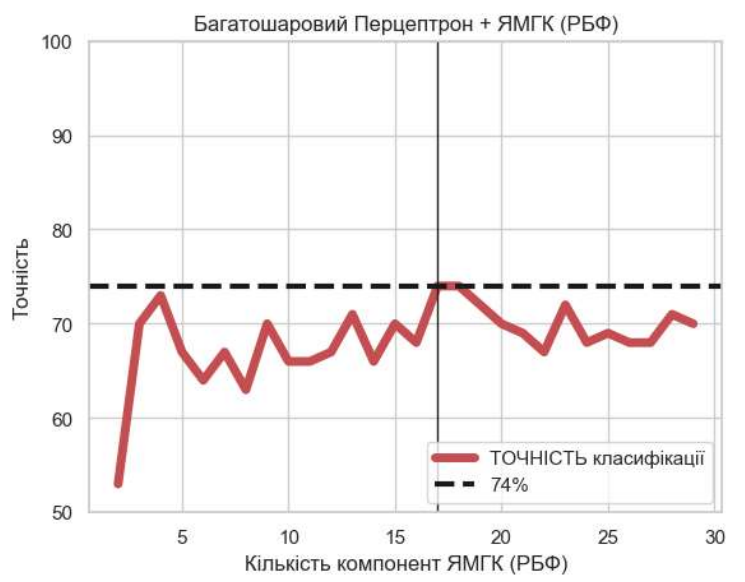

Puc. 10. Точність моделі Багатошаровий перцептрон на ЯМГК (використана радіальна базисна функція) - 74\%

Було обрано найбільш точну модель (логістична регресія та ЯМГК з РБФ) була збережена та імплантована у програмному застосунку (Рис. 11.).

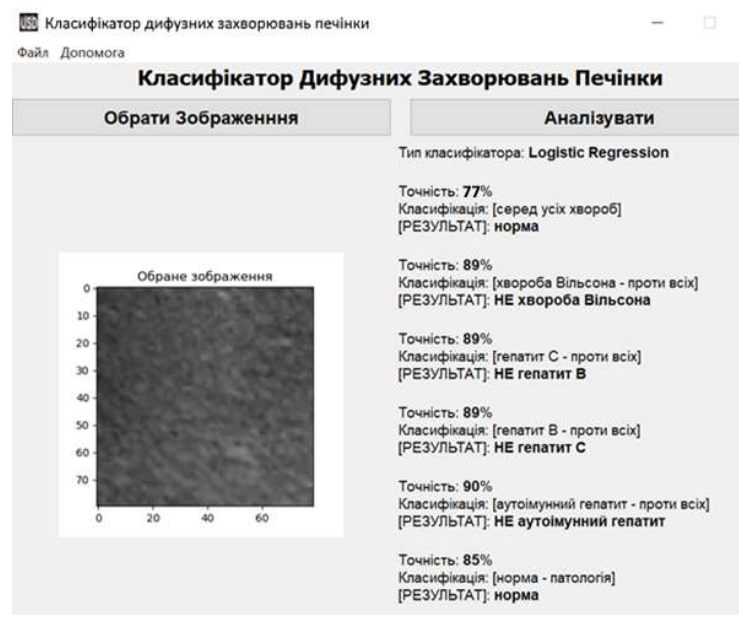

Puc. 11. Програмний за стосунок

Автори публікації висловлюють подяку співробітникам ДУ «Інститут ядерної медицини та променевої діагностики Національної академії медичних наук України» за підтримку виконаної науководослідної роботи 3 обробки медичних зображень сонографії печінки. Особлива подяка д.м.н., с.н.с., заст. директора $з$ наукової роботи Тарасюку Борису Андрійовичу.

\section{VI. ВИСНОВКИ}

Аналіз літературних джерел дозволив встановити, що серед методів діагностики печінки порівнянобезпечним $\epsilon$ сонографія. Було запропоновано використати підхід текстурного аналізу для об'єктивної оцінки стану пацієнта на основі зображень сонографії печінки пацієнта. Цей підхід включає в себе обчислення матриць сірого рівня GLCM, GLRLM, GLSZM, GLDM, NGLDM, а також текстурні ознаки до кожної з цих матриць.

Було застосовано метод ТА до набору клінічних даних сонографії печінки пацієнтів дитячого віку. В ході обробки отриманих даних було відібрано найбільш точну аналітичну модель класифікації мультиноміальна логістичної регресії при ядровому методі головних компонент (на 5 компонентах) при ядрі - радіальній базисній функції - 77\%.

Розроблено програмний додаток, здатний класифікувати нові зображення на уже побудованій моделі класифікації. 


\section{ПЕРЕЛІК ПОСИЛАНЬ}

1. World Health Organization Global hepatitis report, 2017 / World Health Organization. - 2017. - 62 p.

2. Fornari F. Complications following percutaneous liver biopsy promoting group / F. Fornari, A. Francavilla, M. Frezza[et al.] // Liver. - 1986. — Vol. 50, No. 84. - P. 165-173.

3. Tchelepi H. Sonography of diffuse / H. Tchelepi, P. W. Ralls, R. Radin, E. Grant // Ultrasound. - 2002. - Vol. 21, No. 9. - P. 1023-1032.

4. Bataller R. Science in medicine - liver fibrosis / R. Bataller, D. a Brenner // Journal of Clinical Investigation. - 2005. Vol. 115, No. 2. - P. 209-218.

5. Дыкан И. Н. Современный взгляд на проблему лучевой диагностики фиброза печени / И. Н. Дыкан, Н. Е. Новиков, Б. А. Тарасюк // Лучевая диагностика, лучевая терапия. — 2013. - Vol. 4. - P. 67-76.

6. Curley S. A. Radiofrequency ablation of hepatocellular cancer in 110 patients with cirrhosis / S. A. Curley, F. Izzo, L. M. Ellis[et al.] // Annals of Surgery. — 2000. - Vol. 232, No. 3. - P. 381-391.

7. Materne R. Assessment of hepatic perfusion parameters with dynamic mri / R. Materne, A. M. Smith, F. Peeters[et al.] // Magnetic Resonance in Medicine. - 2002. - Vol. 47, No. 1. - P. 135-142.

8. Алешкевич А. И. ОСНОВЫ и принципы лучевой диагностики / А. И. Алешкевич, В. В. Рожковская, И. И. Сергеева, Т. Т. Ф. А. Г.А. - Минск : Белорусский государственный медицинский университет, 2014. — 86 p.

9. Bohte A. E. The diagnostic accuracy of us, ct, mri and 1h-mrs for the evaluation of hepatic steatosis compared with liver biopsy: a meta-analysis / A. E. Bohte, J. R. Van Werven, S. Bipat, J. Stoker // European Radiology. — 2011. - Vol. 21, No. 1. - P. 87-97.

10. Gerstenmaier J. F. Ultrasound in chronic liver disease / J. F. Gerstenmaier, R. N. Gibson // Insights into Imaging. 2014. - Vol. 5, No. 4. - P. 441-455.

11. Nailon W. H. Texture analysis methods for medical image characterisation / W. H. Nailon // Intech. - 2016. - Vol. i,
No. tourism. - P. 13.

12. Haralick R. M. Textural features for image classification / R. M. Haralick, K. S. Shanmugam, I. Dinstein // IEEE Transactions on Systems, Man, and Cybernetics. - 1973. - P. 610-621.

13. Haralick R. M. Statistical and structural approaches to texture / R. M. Haralick // Proceedings of the IEEE. - 1979. — Vol. 67, No. 5. - P. 786-804.

14. Galloway M. M. Texture analysis using gray level run lengths / M. M. Galloway // Computer Graphics and Image Processing. - 1974. - Vol. 4, No. 2. - P. 172-179.

15. Thibault G. Texture indexes and gray level size zone matrix application to cell nuclei classification / G. Thibault, B. Fertil, C. Navarro, S. Pereira // Pattern Recognition and Information Processing. - 2009. — No. November. - P. $140-145$.

16. Sun C. Neighboring gray level dependence matrix for texture classification / C. Sun, W. G. Wee // Computer Vision, Graphics and Image Processing. - 1983. - Vol. 23, No. 3. - P. 341-352.

17. Amadasun M. Texural features corresponding to texural properties / M. Amadasun, R. King // IEEE Transactions on Systems, Man and Cybernetics. — 1989. - Vol. 19, No. 5. - P. 1264-1274.

18. Carlson J. Radiomics package / J. Carlson. - 2015.

19. Lambin P. Radiomics digital phantom / P. Lambin // Cancer Data. - 2016.

20. Grus J. Data science from scratch (2nd edition) / J. Grus // 2019. - P. 409.

21. GORBAN A. N. Principal manifolds and graphs in practice: from molecular biology to dynamical systems / A. N. GORBAN, A. ZINOVYEV // International Journal of Neural Systems. - 2010. - Vol. 20, No. 03. - P. 219 232.

22. Rafiee J. Wavelet basis functions in biomedical signal processing / J. Rafiee, M. A. Rafiee, N. Prause, M. P. Schoen // Expert Systems with Applications. — 2011. Vol. 38, No. 5. - P. 6190-6201. 


\title{
КЛАССИФИКАТОР СОСТОЯНИЯ ПЕЧЕНИ У ДЕТЕЙ С ПАТОЛОГИЕЙ ГЕПАТОБИЛИАРНОЙ СИСТЕМЫ С ТЕКСТУРНЫМИ СТАТИСТИКАМИ УЛЬТРАЗВУКОВОГО ИССЛЕДОВАНИЯ
}

\author{
Настенко Е.А., зав. каф., д.б.н., к.т.н., с.н.с. \\ nastenko.e@gmail.com \\ Янковый И.А., студент \\ illia.yankovyi@gmail.com \\ Факультет биомедицинской инженерии \\ Национальный технический университет \\ г. Киев, Украина
} «Киевский политехнический інститут шимени ИгоряСикорского»

\begin{abstract}
Реферат - По результатам ультразвукового исследования печенки можно диагностировать наличие диффузных заболеваний печени. На входе было получено набор медицински зображений ультразвуковой діагностики печени. В даннойработе к изображениям были применены методы текстурного анализа, в результате чего было получено 96 статистических признаков. Все полученные данные были приведены к стандартному распределению. Количество признаков было сокращена при сохранении значимой информаџии с помощью ядерной методики главных компонентов. Рассмотрено построение модели классификатора, приведено сравнение эффективности модели случайного леса, логистической регрессии и многослойного персептрона. Проведена оценк точности модели с помощью метода перекрестной проверки. Лучший результат показала модель мультиномиальной логистической регрессии - 77\%. Разработана система для прогнозирования возможных патологии печени у детей с помощью текстурного анализа результатов сонографии. Полученная система визуализирует результат прогнозирования и их точность для упрощени процесса приняти решений врачом ультразвуковой диагностики.
\end{abstract}

Ключові слова - классификация, текстурный анализ, текстурные статистики, метод главных компонентов, ядерные методы, перекрестная проверка, диффузные заболевания печени, ультразвуковая диагностика, детские заболевания. 
UDC 004.932.2

\title{
CLASSIFIER OF THE STATE OF THE LIVER IN CHILDREN WITH PATHOLOGIES OF THE HEPATOBILIARY SYSTEM WITH TEXTURAL STATISTICS OF ULTRASOUND
}

Nastenko I.D.Sc. in Biology, $\mathrm{PhD}$ in Engineering, Senior Researcher nastenko.e@gmail.com

Yankovyi I., student illia.yankovyi@gmail.com Faculty of Biomedical Engineering National Technical University of Ukraine "Igor Sikorsky Kyiv Polytechnic Institute"

Kyiv, Ukraine

\begin{abstract}
With the results of ultrasound diagnostics of the liver, it is possible to diagnose the presence of diffuse liver diseases. At the entrance it was received a set of medical images of ultrasound diagnostics of the liver. In this work, texture analysis methods were applied to the images, therefore it was received 96 statistical features. All received data were brought to the standard distribution. The number of attributes has been reduced while retaining significant information through the principal component analysis. The construction of the classifier model is considered, the comparison of the efficiency of the model of random forest, logistic regression and multilayer perceptron is given. The accuracy of the model was evaluated using the cross-validation. The best result got the model of multivariate logistic regression - 77\%. The system for prediction of possible liver disease in children is developed with the help of texture analysis of the results of sonography. The obtained system visualizes the results of prediction and their accuracy in order to simplify the decision-making process of the ultrasound diagnostics doctor.
\end{abstract}

Key words - classification, textural analysis, textural statistics, principal component analysis, kernel methods, crossvalidation, diffuse liverdiseases, ultrasound diagnostics, child hoodillnesses. 